\title{
A Comparative Analysis of Drainage Morphometry on Hydrologic Characteristics of Kereke and Ukoghor Basins on Flood Vulnerability in Makurdi Town, Nigeria
}

\author{
Oyatayo Kehinde Taofik ${ }^{1, *}$, Bello Innocent ${ }^{2}$, Ndabula Christopher ${ }^{3}$, Godwill Geofrey Jidauna ${ }^{3}$, \\ Ademola Sunday James ${ }^{1}$ \\ ${ }^{1}$ Department of Geography, Kwararafa University, Wukari, Nigeria \\ ${ }^{2}$ National Space Research and Development Agency, Abuja, Nigeria \\ ${ }^{3}$ Department of Geography and Regional Planning, Federal University, Dutsin- Ma, Nigeria
}

Email address:

oyatayokehinde@gmail.com (O. K. Taofik)

${ }^{*}$ Corresponding author

\section{To cite this article:}

Oyatayo Kehinde Taofik, Bello Innocent, Ndabula Christopher, Godwill Geofrey Jidauna, Ademola Sunday James. A Comparative Analysis of Drainage Morphometry on Hydrologic Characteristics of Kereke and Ukoghor Basins on Flood Vulnerability in Makurdi Town, Nigeria. Hydrology. Vol. 5, No. 3, 2017, pp. 32-40. doi: 10.11648/j.hyd.20170503.11

Received: June 30, 2017; Accepted: July 18, 2017; Published: August 15, 2017

\begin{abstract}
The synergistic enforcement of the hydrographic behaviors of Kereke and Ukoghor river basins on the river Benue have been identified as the major contributors of the replete episodic flood hazard of Makurdi town. It is on this note that this study aims at analysing and comparing two categories of morphometric parameters; areal and linear/relief which influence runoff/discharge volumes and time lag of Kereke and Ukoghor river basins hydrograpghs respectively. This analysis provides a better understanding of their hydrographic characteristics and vulnerability to the flood hazard. The potential hydrographic variables examined include: runoff, peak flow, time to peak, infiltration, and overland flow. This was achieved using topographical maps of Makurdi sheet $251 \mathrm{NW}$ and $251 \mathrm{SW}$ on scale 1:50,000 published by Federal Survey of Nigeria (1965). These morphometric parameters were evaluated using ArcGIS 10.2 platform. Results indicated that both basins are $5^{\text {th }}$ order basins with dendritic pattern. Kereke and Ukoghor basins have basin area $261.28 \mathrm{~km}^{2} / 94.82 \mathrm{~km}^{2}$, basin length 26 $\mathrm{km} / 10.79 \mathrm{~km}$, basin perimeter $76.28 \mathrm{~km} / 40.15 \mathrm{~km}$, bifurcation ratio $3.51 / 3.09$, length of overland flow $0.56 \mathrm{~km} / 0.42 \mathrm{~km}$, form factor $0.39 / 0.85$, circulatory ratio $0.56 / 0.70$, relief ratio $0.45 / 0.91$, drainage density $0.91 / 1.20$, elongation ratio $0.40 / 0.60$ and infiltration number $0.53 / 1.32$ respectively. A comparison of the results of linear/relief parameters indicate that Okoghor drainage constitute fast peak flow and concentration time of shorter duration and hence higher flood vulnerability than Kereke drainage basin. On the other hand a comparison of areal aspects of morphometry Kereke river basin constitutes more vulnerability to flooding in Makurdi town than Ukoghor river basin with regards to hydrograph volume regimes. The outcome of the study is fundamental for prioritizing proactive and sustainable urban flood management, appropriate land use planning and zonation especially along their flood liable areas, storm water management and other general urban environmental degradation management.
\end{abstract}

Keywords: Morphometry, Drainage Basin, Flood, GIS, Hydrology, Kereke, Ukoghor

\section{Introduction}

Morphometry represents the topographical expression of land by way of area, slope, shape, length, etc. These parameters affect catchment stream flow pattern through their influence on concentration time [1] cited [2]. These landscape parameters are significant because stream flow can be expressed as a general function of geomorphology of a watershed. Geomorphic characteristic of drainage basins play key-role in controlling the basins hydrology. The assertion 
still stand valid following [1], [3], [4], [5] and [6] who reported that the Morphometric analysis of drainage basins thus provides not only an elegant description of the landscape, but also serve as a powerful means of comparing the form and process of drainage basins that may be widely separated in space and time. Morphometric analysis defines more clearly and precisely the general form of the basin landform as represented on a map and serve as a basis for demonstrating the effect of environmental control on fluvial system and for predicting the basin output variables such as discharge [7].

Hydrological response of a drainage basin is defined by the production of runoff against a given rainfall, which in turn is characterized by basin morphometric properties, soil characteristics and land use pattern. While the soil characteristics and land use pattern control the infiltration loss, the distribution of the remaining excess rainfall is governed by basin morphometric properties. Basin area has been identified as the most important of all the morphometric parameters controlling catchment runoff pattern. This is because, the larger the basin, the greater the volume of rainfall it intercepts, and the higher the peak discharge that result. Another reason for the high positive correlation between basin area and discharge is the fact that basin area is also highly correlated with some of the other catchment morphometric characteristics which influence runoff, such as, basin length and stream length. However, other catchment morphometric parameters such as relief, shape and length also influence basin discharge pattern strongly. This is through their varying effects on lag time. These morphometric factors have proved very important when rates of flooding are being compared between two basins [8]; [9]; [10]; [3]; [4]; [10]; [11]; [12]; [3] cited in: [5].

Prior to this time, morphometric parameters were measured using mathematical concepts but Geographic Information System (GIS) modules provide flexible environment and powerful tools for integrating, manipulating and analyzing spatial information [13]. Currently, GIS have gained recognition as preferred data analytical platform for morphometric analyses respectively. For example, GIS has been extensively utilized in various morphometric analyses [14]; [15] cited in: [16]. Today, many GIS platforms are embedded with various types of morphometric-specific algorithms that enable scientists to determine many morphometric parameters automatically, thereby increasing efficiency as well as reducing rigor and time [17]; [16]

Morphological studies of rivers are very important to study the behaviour of a river, its aggradations/degradation, shifting of the river course, flooding and erosion of river bank e.t.c. and to plan remedial measure for erosion, flooding and other related problems [7]. In the present research, effort has been made to study the influence of morphometric variables on flooding in Kereke and Ukoghor drainage basins using GIS. Thus, the result from this investigation will aid in suggesting management techniques that can be adopted in a bid to reduce the recurring floods and land degradation problems being caused by processes operating in the study area.

\section{Study Area}

\subsection{Location of the Study Area}

Makurdi town is situated between latitude $07^{0} 43^{1} \mathrm{~N}$, $07^{0} 45^{1} \mathrm{~N}$ and longitude $08^{0} 32^{1} \mathrm{E}$ and $08^{0} 38^{1} \mathrm{E}$. Makurdi is the capital city of Benue state, traversed by the Benue River which the state's name was derived. The river splits the town into North and South banks respectively. Benue state is found in the Middle belt region of Nigeria. See Figure 3, for the map of Benue State, showing Makurdi. Makurdi is bounded by Tarka L. G. A to the East, Guma to the North, Gwer West to the West and Gwer to the South. The local government is made up of eleven council wards which include: Agan; Ankpa/ Wadate: Bar; Central South Mission; Fiidi, Mbalagh; Market Clark; Modern Market; North Bank I., North Bank II and Wailomayo. See figure 1, for location of the study area on Map of Makurdi Local Government Area.

\subsection{Climate}

The climate of Makurdi town is the tropic Aw type with alternating wet and dry seasons which are also hot and cool. The climate is characterized by SW and NE monsoons. The north south annual movement of intertropical discontinuity (ITD), the convergence zone SW and NE monsoons, synoptic weather systems (such as thunder storms and squall line) and topography influences rainfall distribution in the region.

The rainfall periods are from April to October, with rainfall amount ranging from $900 \mathrm{~mm}$ to $1200 \mathrm{~mm}$ with the heaviest rain in June and September which decline with increasing latitude. Annual rainfall in Makurdi town is consistently high, with an average annual total of approximately $1173 \mathrm{~mm}$ [18]. The mean dates of onset and cessation of the rainy season are $15^{\text {th }}$ April and $14^{\text {th }}$ October respectively.

\subsection{Relief and Drainage}

Makurdi town is generally located in a plain that slopes up gently on either side of the river. Thus, the elevation rises to the north about $154 \mathrm{~m}(500 \mathrm{ft})$ at Daudu, and to the south about $216 \mathrm{~m} \mathrm{(700} \mathrm{ft)} \mathrm{at} \mathrm{Ikpayongo} \mathrm{[19].} \mathrm{The} \mathrm{Benue} \mathrm{River}$ forms the major drainage channel in Makurdi. It flows east to west dividing the region into the north and south banks. Other drainage channels mostly first order streams and the tributaries of River Benue also drain the region. There are also several streams draining Makurdi town on both banks which are tributaries of the River Benue. Most of the streams are perennial and include Kpege, Adaka, Asase, Idye, Urudu and Demekpe amongst others.

\subsection{Geology and Soils}

The geology of Makurdi town consists mainly of sedimentary formation of sandstones. Low lying areas like Wadata are overlain by shale [19]. The sandstone is divided into micaceous and feldspathic sand-stones. The soils of the area are the tropical ferruginous soils that comprise of 
hydrographics along flood plains and wetlands and lithosols of flood plains. The red ferralsols developed on sedimentary rocks are also found in the southern parts. The soils are a reflection of its parent materials developed by slope and climate. The sandy nature of the topsoil makes infiltration easy which explains the usage of shallow wells in the area.
The first aquifer is unconfined with precipitation infiltration through porous sandy environment as water source. The second aquifer also referred to as the semi-confined has the formation of highly consolidated and geologically made of shales intercalated with sandstones of coarse grains exhibiting larger pores.

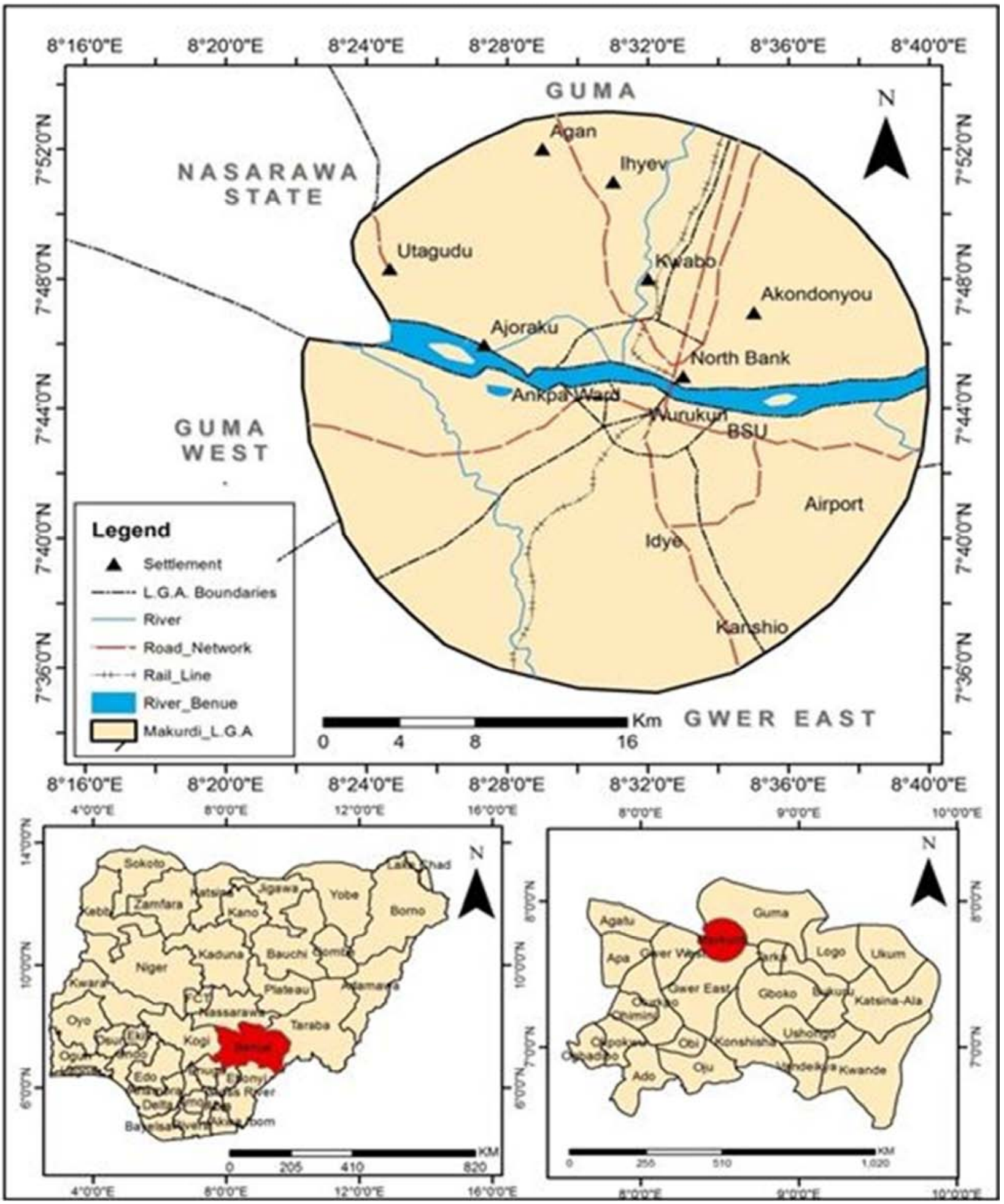

Source: Adapted from the Administrative map of Benue State

Figure 1. Map of Benue State showing study area. 


\section{Materials and Methods}

Methodology adopted in this study includes two stages of analysis. The first stage includes thematic database generation, morphometric parameter evaluation and its description. The second stage looks at interrelationship between morphometric variables and their hydrological significance.

Topographical maps of Makurdi sheet $251 \mathrm{NW}$ and 251 SW on scale 1:50,000, published by Federal Survey of Nigeria in 1965, obtained from the office of the Surveyor General of the Federation were used as fundamental data source for quantifying morphometric parameters. These maps are highly recommended for a study of this nature [2]; [12]; $[20] ;[5]$.

The hard copies of topographic maps of the study area were scanned and saved in GIS compatible format; it was later exported to the ArcGIS 10.2 user interface where the maps were georeferenced and brought to a common spatial reference system (WGS-84/UTM zone $32 \mathrm{~N}$ ) for better analysis. Basin boundaries were delineated and drainage networks manually vectorized from topographical maps as well as updated from recent satellite images. Drainage segments were ordered numerically as suggested by [21] to know the exact order of streams in the basins and Bifurcation ratio $(\mathrm{Rb})$ was used to determine the ratio number of stream segments of given order to the number of segments of the next higher order in the basins.

The choice of morphometric variables that were examined in this study was based on the result obtained from previous studies, which have been found to correlate highly with peak discharge, runoff volumes and sediment delivery [22]; [11]; [23]; [10]; [24]; [5] cited in: [2]. In all, eleven (11) morphometric variables (broadly categorized into three (3) vis; area, linear and relief morphometrics) as suggested by [2] were examined (Table 2 and 3). The procedure used in deriving each of the variables is equally shown in table 1.

Table 1. Basin Morphometric parameter.

\begin{tabular}{|c|c|c|}
\hline CATEGORY & PARAMETER & DERIVATION PROCEDURE \\
\hline \multirow{2}{*}{ Area } & Basin area & Area $=$ map scale $\mathrm{x}$ counted squares (Gregory and walling 1973) \\
\hline & Circulatory ratio & $\mathrm{RC}: 4 \pi \mathrm{A} / 2$ where $\mathrm{RC}=$ circulatory ratio, basin area and $\pi=$ constant (Miller, 1953) \\
\hline Area & Drainage density & $\mathrm{DD}=\sum \mathrm{L} / \mathrm{A} ;$ where $\mathrm{DD}=$ Drainage density, $\sum \mathrm{L}=$ sum of all stream lengths and $\mathrm{A}=$ Basin area (Horton, 1932) \\
\hline Area & Number of streams & $\sum \mathrm{NU}$ : Where $\mathrm{Nu}$ is the stream number and $\sum=$ sum (strauler, 1952) \\
\hline Area & Elongation ratio & $\mathrm{EL}=2 \pi \sqrt{A / L}$ where $\mathrm{EL}=$ elongation ratio, $\mathrm{A}=$ Basin area, $\mathrm{L}=$ Basin length and $\pi$ constant (Schumn, 1956) \\
\hline Area & Form Factor & $\mathrm{F}=\mathrm{A} / \mathrm{L}$ where $\mathrm{F}=$ form factor, $\mathrm{A}=$ Area of the basin and $\mathrm{L}$ length of the basin (Boyce and clark, 1964) \\
\hline Linear & Basin length & This is the straight line from the mouth of the basin to the farthest point on the basin perimeter (schumm, 1956) \\
\hline Linear & Average stream length & Total stream length divided by total number of streams (Schumm, 1963) \\
\hline Linear & Main stream length & This is the length of the principal drainage line (Schumm, 1963) \\
\hline Relief & Relief ratio & $\begin{array}{l}\mathrm{Rh}=\mathrm{H} / \mathrm{L} \text { where } \mathrm{Rh}=\text { relief ratio, } \mathrm{H}=\text { horizontal distance along the longest dimension parallel to the principal } \\
\text { drainage line and } \mathrm{L}=\text { Length of the basin along the principal drainage line (Schumm, 1956) }\end{array}$ \\
\hline
\end{tabular}

Source: Ajibade, Ifabiyi, Iroye and Ogunteru (2010)

Table 2. Drainage basin linear/relief morphomertic parameters.

\begin{tabular}{lll}
\hline Morphometric parameter & Kereke Basin & Ukoghor Basin \\
\hline $1^{\text {st }}$ order (Number of segments) & 98 & 72 \\
$2^{\text {nd }}$ order,, & 44 & 17 \\
$3^{\text {rd }}$ order, & 7 & 9 \\
$4^{\text {th }}$ order, & 2 & 2 \\
$5^{\text {th }}$ order, & 1 & 1 \\
$\sum \mathrm{Nu}$ & 152 & 101 \\
$\sum \mathrm{Lu}(\mathrm{km})$ & 238.35 & 118 \\
$\mathrm{R}_{\mathrm{b}}$ & 3.51 & 3.09 \\
$\mathrm{Lb}(\mathrm{km})$ & 26.00 & 10.79 \\
$\mathrm{Rh}$ & 0.45 & 0.91 \\
\hline
\end{tabular}

Where; $\mathrm{Rh}=$ Relief ratio; $\mathrm{R}_{\mathrm{b}}=$ Bifurcation ratio; $\mathrm{Lb}=$ basin length; $\mathrm{Nu}=$ total no. of stream segments of order; $\mathrm{Lu}=$ the total stream length of order

Table 3. Drainage basin Linear and Areal morphometric parameters.

\begin{tabular}{lll}
\hline Morphometric parameter & Kereke basin & Ukoghor basin \\
\hline Area $\left(\mathrm{km}^{2)}\right.$ & 261.28 & 94.82 \\
Drainage density (D) & 0.91 & 1.20 \\
Stream frequency (f) & 0.58 & 1.10 \\
Form factor (Rf) & 0.39 & 0.85 \\
Elongation ratio (Re) & 0.40 & 0.60 \\
Circularity ratio (Rc) & 0.56 & 0.70 \\
Infiltration number & 0.53 & 1.32 \\
Length of overland flow (Lg) & 0.56 & 0.42 \\
\hline
\end{tabular}

\section{Results and Discussion}

Figure 2 and 3 shows that the Kereke and Ukoghor basins exhibits dendritic type of drainage network which indicate the homogeneity in texture and lack of structural control in the study area. Tables 1 and 2 represent values pertaining to linear, areal and relief aspects of drainage morphometry in Kereke and Ukoghor drainage basins. Linear aspects of the basin are proportionately related to stream order and reflects the geomorphologic evolution of basin ([26] cited in: [28]). It includes stream order, bifurcation ratio, stream length, infiltration number and length of overland flow. Areal aspect of basin includes drainage basin area, drainage density, stream frequency and basin shape (form factor, circularity ratio and elongation ratio). The relief aspect of basin morphometry indicates vertical dimension of drainage basin which relates to the relief ratio of the two basins.

\subsection{Stream Order}

Stream ordering is the first step in drainage basin analysis. Stream order has been defined as a measure of the position of 
a stream in the hierarchy of tributaries. Hierarchical ordering of streams is necessary to assess hydrodynamic character of a drainage basin [7]. Both intermittent and permanent flow lines were included for stream ordering. This research adopts [29] method of stream ordering system. The total number of stream segments is found to decrease as the stream order increases in Kereke and Ukoghor drainage basins respectively. In total, 253 stream segments were identified, out of which $67.2 \%$ (170) are first-order, $24.1 \%$ (61) are second-order, $6.3 \%$ (16) are third-order, $1.6 \%$ (4) are fourthorder and $0.8 \%$ (2) are fifth-order. Kereke and Ukoghor basins are both fifth order basins. The law of stream number states that the numbers of stream segments of each order form an inverse geometric sequence with order number [30]. The Law of stream number was found to be consistent for both Kereke and Ukoghor basins.

Lower order streams are considered as the primary collector of rainfall and better flood predictor ([26] cited in: [28]). For a large basin, the order number is directly proportional to watershed dimension, channel size and stream discharge [31]. In other words, the amount of water drained by stream increases with order. Based on this, Kereke basin has higher number of lower order streams than Ukoghor basin; hence, it is expected to yield more water in particular storm than Ukoghor basin.

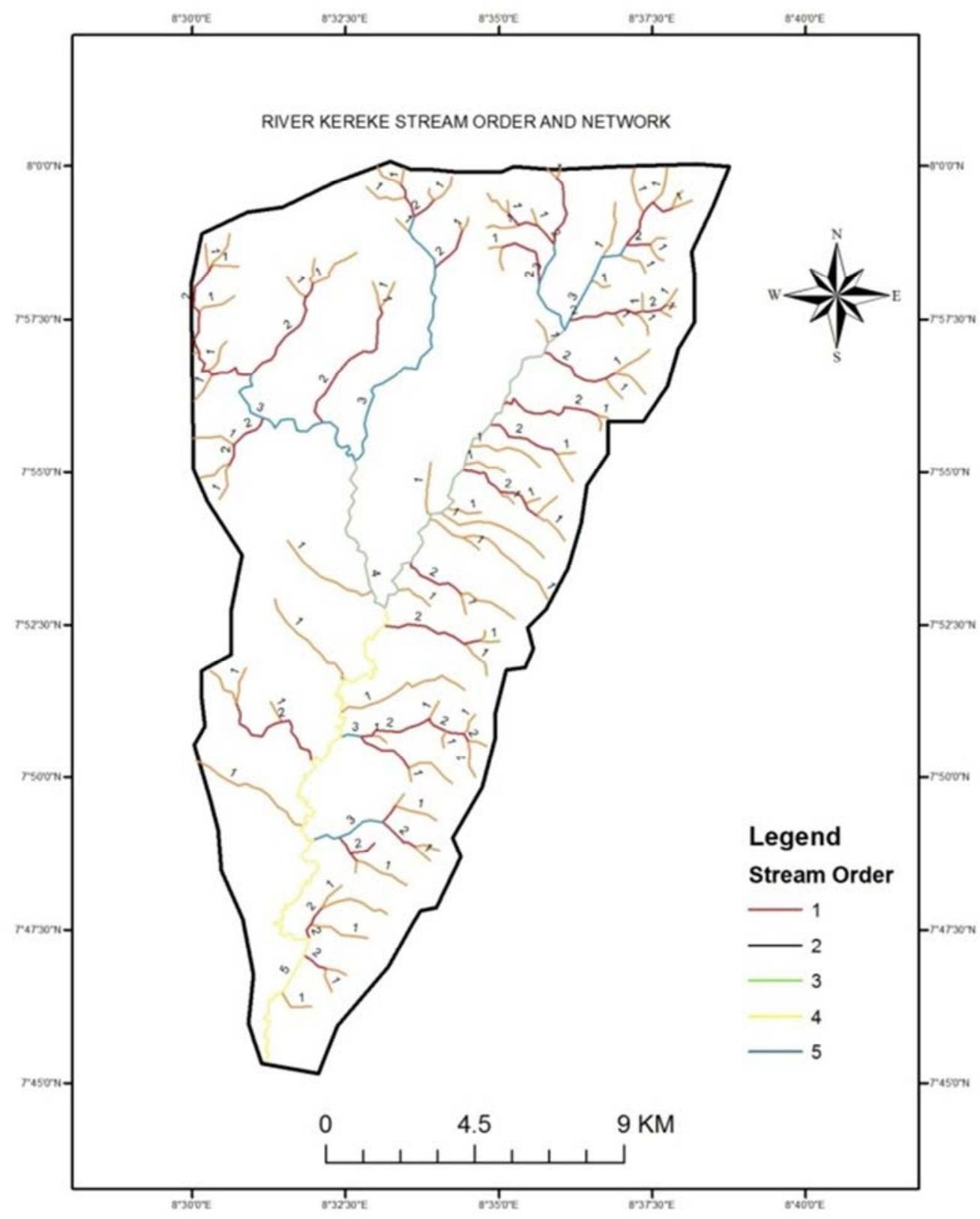

Source: Topographic Map based analysis of Makurdi Sheet 251 NW

Figure 2. River Kereke stream order and drainage network. 


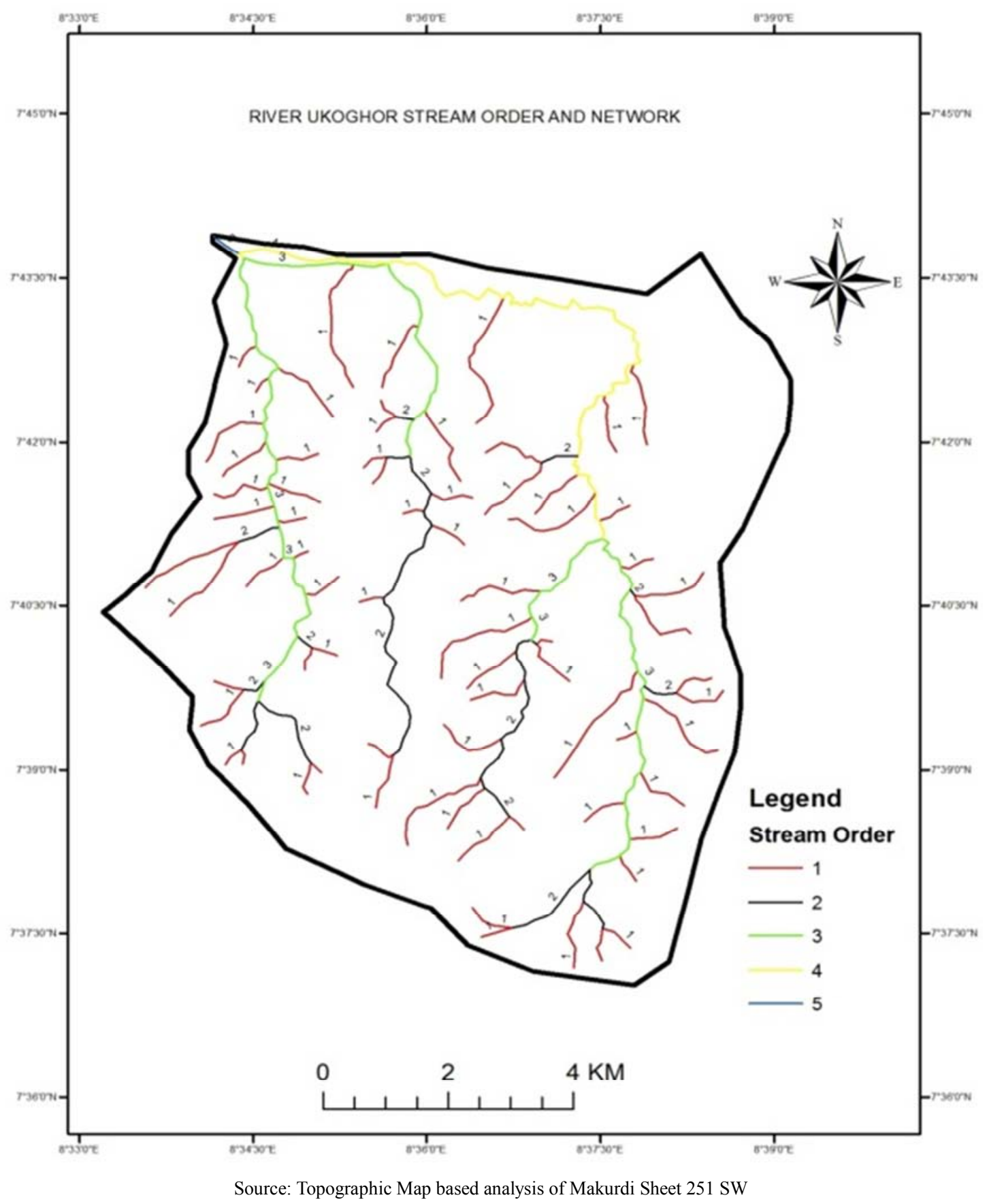

Figure 3. River Ukoghor Stream Order and drainage network.

\subsection{Bifurcation Ratio (Rb)}

It is computed as the number of stream segments of any given order to the number of streams of the next higher order. It is a dimensionless quantity expressing the form of drainage basin. The value of $\mathrm{Rb}$ is highly stable and shows a small range of variation from region to region or environment to environment, except where powerful geologic controls dominate. Higher $\mathrm{Rb}$ value indicates high structural complexity and low permeability of subsurface strata. The bifurcation ratio is indicative of shape of the basin also. An elongated basin is likely to have a high $\mathrm{Rb}$, whereas a circular basin is likely to have low Rb. After studying a diverse range of drainage basins, [32] states that bifurcation ratio ranges about 2 for flat area, up to 3 for rolling drainage basin and 4 for highly dissected or mountainous basin. In similar conclusion, Strahlar stated that $\mathrm{Rb}$ value characteristically range from 3.0 to 5.0 for watershed in which the geologic structure do not distort the drainage pattern ([29] cited in: [33]).

Average bifurcation ratio for the two basins is 3.3 , with Kereke basin having 3.51 and Ukoghor basin 3.09. With these $\mathrm{Rb}$ values, it is indicative that the geology of the two basins does not distort the drainage pattern of these basins; hence, the drainage pattern in the basin is highly influenced 
by topography and slope rather than structurally controlled. Also, the result obtained is an indication of the fact that Ukoghor basin is more compact than Kereke basin. The implication of this is that Ukoghor basin will have shorter stream length than Kereke basin and will always experience peak flow within a shorter duration and will experience higher incidences of flooding.

\subsection{Stream Length}

Stream length is one of the fundamental linear properties of drainage network, which deals with measurement of channel length of a given order. Mean stream channel length of given order is computed by the combined length of all streams of a particular order to the total number of stream segments in that order. The mean stream channel length of a given order is more than that of lower order and less than the next higher order [33]. There is a total of $238.35 \mathrm{~km}$ length of drainage network in Kereke basin of which first order is $104.9 \mathrm{~km}$ and $68.9 \mathrm{~km}, 25 \mathrm{~km}, 17 \mathrm{~km}, 22.5 \mathrm{~km}$ are second, third, fourth and fifth order respectively. The law of stream length, states that mean length of stream segments of each successive order of a basin tend to approximate a direct geometric sequence. Mean channel length of stream segments is found to be maximum at the $5^{\text {th }}$ order streams of the two basins and minimum at the first order streams. Law of stream length was found to be consistent for both Kereke and Ukoghor basins.

\subsection{Infiltration Number (If)}

The infiltration number of a watershed is defined as the product of drainage density and stream frequency and gives an idea about the infiltration characteristics of the watershed. The higher the infiltration number, the lower will be the infiltration and the higher will be the run-off generated [33]. Kereke and Ukoghor drainage basins have infiltration number of 0.53 and 1.32 respectively. The implication of this is that Ukoghor basin will have lower infiltration rate and higher run-off generated and more liable to flooding than kereke basin.

\subsection{Length of Overland Flow (Lg)}

Length of overland flow $(\mathrm{Lg})$ relates to the length of water over the ground before it becomes concentrated into definite stream channels. It is considered the most crucial independent variable affecting hydrological and geomorphological development of drainage basins. It is an important independent variable affecting both the hydrologic and physiographic development of drainage basin [32]. It affects both runoff and flooding processes. During overland flow, the infiltration process takes place for entire basin. In high relief areas, lower order streams quickly joins under the influence of slope, thus minimizes $\mathrm{Lg}$ and time of concentration. Higher $\mathrm{Lg}$ value provides longer concentration time and favourable condition for sheet erosion/infiltration under sparse/dense vegetation cover. In small river basin, length of overland flow is a dominant hydrological process that has significant effect on the shape of hydrograph ([28]; [33]). Ukoghor and Kereke basins have $\mathrm{Lg}$ value of 0.55 and 0.42 respectively. Because Kereke drainage basin has higher length of overland flow, this will provide longer concentration time and favourable condition for infiltration within the basin; unlike in Ukoghor basin, where concentration time will be shorter and condition for infiltration will be less.

\subsection{Drainage Basin Area}

Basin area has been identified as the most important of all the morphometric parameters controlling catchment runoff pattern. This is because, the larger the basin, the greater the volume of rainfall it intercepts, and the higher the peak discharge that result ([8]; [9]; [10]; [3]; [4]). Another reason for the high positive correlation between basin area and discharge is the fact that basin area is also highly correlated with some of the other catchment morphometric characteristics which influence runoff, such as, basin length and stream length ([11]; [12]; [3]; [5] cited in [2]). However, other catchment morphometric parameters such as relief, shape and length also influence basin discharge pattern strongly. This is through their varying effects on lag time. These morphometric factors have proved very important when rates of flooding are being compared between the two basins being investigated in this study. Though, Ukoghor is smaller in size, the basin has recorded more flood events in the city than Kereke drainage basin, which is larger in size. The reason for this as observed by [2] in their study of Ogbere and Ogunpa drainage basins can be traced to the difference in basin length. Kereke drainage basin is larger in size, a factor which affect its length (the larger the basin, the longer its length). The longer the length of a basin, the lower the chances that such a basin will be flooded when compared with a more compact basin like Ukoghor with shorter basin length (table 1). This is because, the longer the basin, the lower its slope. Not only this, time of concentration (lag time) in such a basin will be higher than a more compact basin which produces sharp hydrographic peak. This will lead to rapid withdrawal of water from such a basin. High concentration time thus exposes the water intercepted by Kereked drainage basin to longer duration of infiltration and evaporation process, hence reduction in runoff volume.

\subsection{Drainage Density}

Drainage density is the stream length per unit area in region of watershed [32]. It indicates the closeness of channel spacing and provides a numerical measurement of land form dissection and runoff potential. Low drainage density is the characteristics of highly resistant or highly permeable sub-soil material, under dense vegetation cover, where the relief is low. High drainage density in the region of weak or impermeable sub-surface material, sparse vegetation and mountainous relief. Drainage density is controlled by numerous variables including relief, rainfall and infiltration capacity of the terrain and resistance of land 
to erosion ([32]; [28]). It is used as an important independent variable for formulating other morphometric parameters such as length of overland flow, ruggedness number and constant of channel maintenance. Kereke and Ukoghor basins have 0.91 and 1.20 drainage density respectively. [2] asserts that when comparing two drainage basins, the basin with higher drainage density, higher relief and circulatory ratio will have higher incidences of flooding. Based on this assumption, Ukoghor drainage basin will have higher incidences of flooding than Kereke basin.

\subsection{Form Factor}

According to [30] cited in [33] form factor may be defined as the ratio of basin area to square of the basin length. The value of form factor would always be less than 0.754 (for a perfectly circular watershed). Smaller the value of form factor $(<0.45)$, more elongated will be the watershed. The watershed with high form factors have high peak flows of shorter duration, whereas elongated watershed with low form factor ranges from 0.42 indicating them to be elongated in shape, hence, will have peak flow for longer duration [34]. Ukoghor and Kereke basins have form factor of 0.85 and 0.39 respectively. This indicates that Ukoghor basin will have peak flows with shorter duration and will experience higher incidences of flooding. Kereke basin is elongated in shape, will experience longer duration of peak flow; hence, low incidences of flooding. This is similar to the findings of [34].

\subsection{Relief, Circularity and Elongation Ratio}

Relief ratio $(\mathrm{Rh})$ is defined as the ratio of maximum basin relief to the longest horizontal distance of the basin measured parallel to the major stream. Rh measures the overall steepness of the drainage basin and an important indicator of the intensity of erosion processes operating due to slope in a basin. Relief ratio is directly related to length of overland flow and time to peak. Kereke and Ukoghor basins have relief ratio of 0.45 and 0.91 respectively. Ukoghor river basin has higher relief ratio when compared with Kereke river basin hence, the higher erosive capacity and sediment yields which disposes the basin to higher flood peaks. This confirms the work of [2] who conducted a research on the morphometric analysis of Ogunpa and Ogbere drainage basin and concludes that higher relief ratio in basins leads to higher erosive capacity and sediment yields which disposes the basin in question to higher flood peaks.

Circularity ratio (Rc) is defined as the ratio of basin area to the area of the circle having same perimeter as the basin. Lower Rc value indicates elongated shape of drainage basin, while higher values indicates that the basin shapes are circular. Drainage basins with higher circularity ratio are more exposed to flooding incidence because such basins will always experience shorter time lag, shorter time of rise and higher hydrographic peak [2]. Kereke and Ukoghor basins have circularity ratio of 0.53 and 0.76 respectively. Higher circulatory ratio recorded by Ukoghor drainage basin is in conformity with [2] proposition. The shorter the basin length, the closer to one (1) the circulatory ratio.

According to [35] cited in [33] elongation ratio is defined as the ratio of diameter of a circle of the same area as the basin to the maximum basin length. They observed that this ratio runs between 0.6 and 1.0 over a wide variety of climatic and geologic types. The varying slopes of watershed can be classified with the help of the index of elongation ratio, i.e. circular (0.9-1.0), oval (0.8-0.9), less elongated (0.7-0.8), elongated $(0.5-0.7)$, and more elongated $(<0.5)$. Kereke and Ukhoghor basins have 0.4 and 0.6 circularity ratio indicating that the slope of these basins can be classified as more elongated and elongated. It has been concluded that a circular basin is more efficient in runoff than an elongated basin [34]. Hence, Ukhoghor basin will be more efficient in runoff and higher hydrographic peak.

\section{Conclusion}

This study has attempted to examine the morphometric characteristics of Kereke and Ukoghor Drainage Basins, Makurdi, Nigeria, with a view to assessing the influence of area, linear and relief morphometric parameters on the hydrological processes within these basins. The study shows that the drainage network of the two basins is not structurally controlled. The study also shows that Ukoghor basin is having shorter length of overland flow, bifurcation ratio and higher infiltration number, relief ratio, circularity ratio and elongation ratio. Ukoghor basin has shorter basin length and more compact than Kereke basin.

The conclusion from here is that Okoghor drainage basin morphometric variables are likely to cause high peak flow and concentration time of shorter duration thereby inducing high magnitude flood within the basin compared with morphometric properties of Kereke drainage basin. This research has demonstrated the influence of morphometric parameters on hydrological processes within a drainage basin. It is worthy of note that this influence is however is encouraged by other basin characteristics such as climate, soil characteristics and land use pattern which acts as contributory factors to flooding in drainage basins. The following are management practices that can be adopted by decision makers, environmental managers and planners in these basins to make the environment friendly and to reduce incidences of flood:

(1) More concrete drainages should be constructed that will channel runoff to river Benue at Makurdi.

(2) Efforts should be put in place to reduce the size of paved surfaces in these basins by implementing a robust agro forestry programme at the grass root level.

(3) Advocacy groups should be created and saddled with the responsibility of enlightening households and the public on floods, adaptive measures and the dangers inherent in indiscriminate dumping of refuse in water ways. 


\section{References}

[1] Jones, J. A. A. (1999), Global Hydrology: Processes, Resources and Environmental Management, Longman, $399 \mathrm{pp}$.

[2] Ajibade, L. T., Ifabiyi, I. P., Iroye, K. A., and Ogunteru, S. (2010). Morphomertic Analysis of Ogunpa and Ogbere Drainage Basins, Ibadan, Nigeria. Ethiopean Journal of Environmental Studies and Management, Vol. 3, number 1: 13-19.

[3] Jain, V. and Sinha, R. (2003) Evaluation of Geomorphic Control on Flood Hazard through Geomorphic Instantaneous Unit Hydrograph. Current Science, 85 (11), 26-32.

[4] Okoko, E. E. and Olujinmi, J. A. B. (2003), The Role of Geomorphic Features in Urban Flooding: The case of Ala River in Akure, Nigeria. Int. Journal of Environmental Issues, 1 (1), 192-201.

[5] Ifabiyi, I. P. (2004), a Reduced Rank Model of Drainage Basin Response to Runoff in Upper Kaduna Catchment of Northern Nigeria. Geostudies Forum, 2 (1), 109-117.

[6] Easthernbrook, D. J. (1993), Surface Processes and Landforms, Macmillian Publishing Co., New York, 325 pp.

[7] Oruonye, E. D., Ezekiel, B. B., Atiku, H. G., Baba, E. and Musa, N. I. (2016). Drainage basin morphometric parameters of River Lamurde: Implication for hydrologic and Geomorphic processes. Journal of Agriculture and Ecology Research International, 5 (2): 1-11.

[8] Morisawa, M. E. (1959), Relation of Morphometric Properties to Runoff in the Little Mill Creek, Ohio Drainage Basin, (Columbia University, Dept. of Geol.) Technical Report, 17, office of Naval Research, Project NR 389-042.

[9] Faniran, A and Ojo, O. (1980), Man's Physical Environment, Heinemann Educational Books, London, 404 pp.

[10] Pitlick, J. (1994), Relations between Peak flows, Precipitation and Physiography for Five Mountainous Regions in Western U.S.A., Journal of Hydrology, 158, 219-240.

[11] Gregory, K. J. and Walling, D. E. (1973), Drainage Basin Form and Process: A Geomorphological Approach, Edward Arnold, London, 456 pp.

[12] Ebisemiju, F. S. (1976), the Structure of the Inter-relationship of Drainage Basin Characteristics, Unpublished Ph. D. Thesis, University of Ibadan, Ibadan, $321 \mathrm{pp}$.

[13] Adegoke, K. M. and Bulus, L. G. (2015). Hydrological and morphometric analysis of Upper Yedzam catchment of Mubi in Adamawa State, Nigeria, using GIS. World Environment, 5 (2): 63-69.

[14] Nag, S. K., \& Anindita, L. (2011). Morphometric Analysis of Dwarakeswar Watershed, Baukura District, West Bengal, India, using Spatial Information Technology. IJWREE, 3 (10), 212-219.

[15] Somashekar, R. K., \& Ravikumar, P. (92011). Runoff Estimation and Morphometric Analysis for Hesaraghatta Watershed, A Remote Sensing and GIS Approach. Journal of Indian Society of Remote Sensing, 39 (1), 95-106.

[16] Akinwumiju, A. S and Olorunfemi, M. O. (2016). Morphometric Analysis of Osun Drainage Basin, South western Nigeria. Journal of Geography and Geology, Vol. 8, number 4: 9-22.

[17] Schmidt, J., \& Dikau, R. (1999). Extracting Geomorphometric Attributes and Objects from Digital Elevation Models semantics, Methods, Future Needs. In: Dikau, R. and Saurer, H. (Eds.). GIS for Earth Surface Systems. Gebruder Borntraeger, D - 14129, Berlin. D-70176 Stuttgart, 152-173.

[18] Abah, R. C. (2013). An application of GIS in mapping flood risk zones in a north central City in Nigeria.

[19] African Journal of Environmental Science and Technology. Vol.7 (6), pp.365-371.

[20] BSU Geography Department, field work manual (2016). Local field work manual for Geography Students, Benue State University, Makurdi, Benue State, Nigeria.

[21] Adejuwon, J. O., Jeje, L. K. and Ogunkoya, O. O. (1984), Hydrological Response Patterns of some Third Order Streams on the Basement Complex of Southwestern Nigeria, Hydrological Science Journal, 28 (3), 377-391.

[22] Strahler, A. N. (1964). Hand book of applied hydrology. In: Chow VT, editor. Quantitative geomorphology of drainage basins and channel networks. New York, NY: Mc-Graw Hill Book Company; p. 39-76.

[23] Morisawa, M. E. (1962), Quantitative Geomorphology of Some Watersheds in the Appalachian Plateau, Geol. Soc. Amer. Bull 73, 1025-1046.

[24] Oyegun, R. O. (1980), the Effects of Tropical Rainfall on Sediment Yield from Different Land use Surface in Sub-urban Ibadan, Unpublished Ph. D. Thesis, University of Ibadan, Ibadan.

[25] Jeje, L. K. (1999), Landuse and Sediment Yield in Parts of Southwestern Nigeria, Geografia Fisica Dinanio Quarternaria (Italy), 22, 27-29.

[26] Ritter, D. F., Kochel, R. C., Miller, J. R. (1995). Process Geomorphology. Long Grove, IL: Waveland Press Inc.

[27] Dipak, R. S., Shirish, S. D. and Nagarajan, R. (2014). GIS based drainage morphometry and its influence on hydrology in parts of Western Ghats Region, Maharashtra, India, Geocarto International, DOI: 10.1080110106049.2014.978903.

[28] Horton, R. E. (1932), Drainage Basins Characteristics, Trans. America Geophys. Union, 13, 350-361.

[29] Horton, R. E. (1945). Erosional development of streams and their drainage basins; Hydrophysical Approach to quantitative morphology. Bull Geol Soc Am. 56: 275-370.

[30] Kuldeep, P. and Upasana, P. (2011). Quantitative Morphometric analysis of a watershed of Yamuna Basin, India Using ASTER (DEM) data and GIS. International Journal of Geomatic and Geosciences, Vol. 2, number 1: 248-269.

[31] Yahya, F., Omar, A. and Ali, S. (2016). Morphometric Analysis and flash floods assessment for drainage basins of the Ras En Naqb Area, South Jordan using GIS. Journal of Geoscience and Environment Protection, 14, 9-33.

[32] Schumm, S. A. (1963), a Tentative Classification of River Channels. U. S. Geol. Survey Circular, 477 (10 pp). 